\title{
Perlindungan Hukum terhadap Barang Kiriman Konsumen Pengguna Jasa Go-Send Instant Courier Melalui Tokopedia
}

\author{
Rochati Mahfiroh \\ Program Pascasarjana Fakultas Hukum Universitas Islam Indonesia \\ Jln. Cik Di Tiro No. 1, Yogyakarta, 55223 \\ rochati_mahfiroh@yahoo.com
}

\begin{abstract}
Information technology can be a double-edged sword, because in addition to contributing to the improvement of welfare and the advancement of human civilization, it can also be an effective means of illegal acts. In the context of online transportation, amongst the services provided by Go-Jek Indonesia, Go-Send is the most prone to law violations. This research is a qualitative study with an empirical juridical approach. The object of research is the case of lost goods in the use of the Go-Jek Gosend Instant Courier delivery service feature in the largest marketplace channel in Indonesia, namely Tokopedia. This research attempts to answer questions about Go-Jek and Tokopedia's responsibility for the loss of consumer goods and legal efforts that can be taken if the security of the goods is not fulfilled. Based on the results, it is concluded that Tokopedia and Go-Jek are legally responsible for the loss of goods when transporting goods through Go-Send Instant Courier ordered through the Tokopedia application. Both of them are responsible according to the principle of fault liability. Consumers can take three legal routes: First, file a complaint through the complaint feature provided by Tokopedia; Second, file a lawsuit to BPSK; Third, file a civil suit to the District Court.
\end{abstract}

Key Words: Delivery of goods; legal protection; online transactions

\begin{abstract}
Abstrak
Teknologi informasi bisa menjadi pedang bermata dua, karena selain memberikan kontribusi bagi peningkatan kesejahteraan dan kemajuan peradaban manusia, dapat sekaligus menjadi sarana efektif untuk perbuatan melawan hukum. Dalam konteks transportasi online, dari layanan yang disediakan oleh Go-Jek Indonesia, Go-Send adalah layanan yang paling rawan terjadinya pelanggaran hukum. Penelitian ini merupakan penelitian kualitatif dengan pendekatan yuridis empiris. Adapun objek penelitiannya adalah kasus kehilangan barang dalam penggunaan fitur jasa pengiriman Go-Jek Gosend Instan Courier di dalam kanal jual beli lokapasar (marketplace) terbesar di Indonesia, yaitu Tokopedia. Penelitian ini mencoba menjawab pertanyaan tentang tanggung jawab Go-Jek dan Tokopedia atas kehilangan barang konsumen dan langkah hukum yang dapat ditempuh apabila keamanan barang tidak terpenuhi. Berdasarkan hasil penelitian, disimpulkan bahwa Tokopedia dan Go-Jek bertanggung-jawab secara hukum atas terjadinya kehilangan barang saat pengangkutan /pengiriman barang melalui Go-Send Instan Courier yang dipesan melalui aplikasi Tokopedia. Keduanya bertanggungjawab menurut prinsip tanggungjawab karena kesalahan (fault liability). Konsumen dapat menempuh tiga jalur hukum: Pertama, mengajukan komplain melalui fitur komplain yang disediakan Tokopedia; Kedua, mengajukan gugatan kepada BPSK; Ketiga, mengajukan gugatan perdata kepada Pengadilan Negeri.
\end{abstract}

Kata-kata Kunci: Perlindungan hukum; pengiriman barang; transaksi online 


\section{Pendahuluan}

Era globalisasi yang disusul dengan perkembangan teknologi digital yang begitu canggih membuat perkembangan dunia maya semakin pesat, tidak saja dalam konteks interaksi sosial antar pengguna internet, tetapi juga merambat pada lahirnya beragam bisnis virtual, baik berbentuk start up, peer to peer lending (P2PL) untuk sektor financial service.

Bisnis virtual yang memanfaatkan sistem internet (online) ini biasa disebut dengan electronic commerce atau populer dengan sebutan e-commerce ${ }^{1}$. E-commerce memiliki beberapa karakteristik yaitu: adanya transaksi antara kedua belah pihak; terdapat pertukaran barang, jasa, atau informasi; menggunakan media internet; mengandalkan kepercayaan antara kedua belah pihak karena dilakukan tanpa adanya tatap muka. ${ }^{2}$ Layanan e-commerce terus mengalami peningkatan dari tahun ke tahun dengan berbagai fasilitas layanan barang dan jasa tersedia yang bisa diakses hanya dalam genggaman tangan. Fasilitas layanan tersebut bahkan hampir menyentuh segala lini kehidupan manusia modern, mulai dari dompet/uang digital, jasa transportasi, jasa kurir, hingga jasa pijat (massage) yang berbasis online.

Go-Jek Indonesia merupakan salah satu dari beberapa bentuk e-commerce yang menyediakan layanan online untuk hampir semua kebutuhan penunjang aktivitas manusia. Go-Jek Indonesia merupakan aplikasi berbasis teknologi yang berada di bawah naungan PT. Aplikasi Karya Anak Bangsa. Dari berbagai pelayanan Go-Jek Indonesia, pelayanan jasa transportasi online termasuk layanan yang paling utama, sejak awal jasa transportasi adalah layanan pertama Go-jek Indonesia. Hal tersebut tentu sangat membantu terpenuhinya kebutuhan manusia secara cepat dan mudah. Meskipun demikian, di lain sisi teknologi informasi bisa menjadi pedang bermata dua, karena selain memberikan kontribusi bagi peningkatan kesejahteraan, kemajuan dan peradaban manusia, sekaligus menjadi sarana efektif perbuatan melawan hukum. ${ }^{3}$ Dalam konteks transportasi online, dari beberapa layanan yang tersedia di PT Go-Jek Indonesia di atas, layanan GoSend adalah layanan yang paling rawan terjadinya pelanggaran hukum.

Terdapat celah dalam layanan Go-Send ini: rawan hilangnya barang titipan konsumen. Di mana barang titipan konsumen sangat rawan untuk dicuri/dibawa kabur oleh driver Go-Jek. Seperti yang terjadi pada Yassier, dia membeli barang di Tokopedia pada 7 September 2018 dan memilih mengirimkan barangnya lewat

\footnotetext{
${ }^{1}$ Ahmad M Ramli, Cyber Law dan HAKI dalam Sistem Hukum Indonesia, Refika Aditama, Jakarta, 2004, hlm. 1.

${ }^{2}$ Haris Faulidi Asnawi, Transaksi Bisnis E-Commerce Perspektif Islam, Magistra Insania Press, Yogyakarta, 2004, hlm. 15.

3 Ahmad M Ramli, Menuju Kepastian Hukum di Bidang Informasi dan Transaksi Elektronik, Departemen Komunikasi dan Informatika Republik Indonesia, Jakarta, 2007, hlm. 1.
} 
layanan Go-Send, pada 8 September 2018 seller Tokopedia mengirim barangnya sesuai permintaan dari Yassier (Go-Send). Pengiriman barang dari Gambir, Jakarta ke Tangerang. Dia mengaku bahwa seller Tokopedia mengirimkan pesanannya pada $14.00 \mathrm{WIB}$, setelah menunggu beberapa menit, tiba-tiba muncul notifikasi dari Tokopedia bahwa pesanan sudah sampai. Dia mulai curiga dan merasa ada yang aneh, pasalnya barangnya belum dia terima. Alhasil benar dugaannya, bahwa barang pesanannya dibawa kabur oleh driver Go-Send ini. ${ }^{4}$

Di sisi lain, kriminalitas/kejahatan yang terjadi di internet sangat sulit dan banyak yang tidak terdeteksi. Jumlah jaringan yang terus berkembang semakin luas dan jumlah pengguna yang semakin banyak seringkali membuat pihak berwenang kesulitan untuk menindak tegas pelakunya. ${ }^{5}$

Ditinjau dari aspek hukum perjanjian, salah satu kewajiban paling pokok bagi perusahaan angkutan umum dan konsumen diatur di dalam ketentuan Pasal 186 Undang-Undang No. 22 Tahun 2009 tentang Lalu Lintas dan Angkutan Jalan yang berbunyi: perusahaan angkutan umum wajib mengangkut orang dan/atau barang setelah disepakati perjanjian angkutan dan atau dilakukan pembayaran biaya angkutan oleh penumpang atau pengirim barang. Ketentuan Pasal 186 UU No. 22 Tahun 2009 ini menjelaskan objek perjanjian antara perusahaan angkutan umum dan penumpang atau pengirim barang.

Dalam konteks penggunaan jasa Go-Send atau transaksi pengangkutan jasa kurir ini, perjanjian yang digunakan adalah Perjanjian Baku. Perjanjian baku adalah suatu perbuatan hukum di mana satu pihak saling mengikatkan diri dengan pihak lainnya yang isi perjanjiannya telah disiapkan oleh salah satu pihak, untuk kemudian disetujui atau ditolak oleh pihak lainnya. ${ }^{6}$ Selain itu, celah yang bisa merugikan konsumen dalam bisnis pengantaran ini (Go-Send) adalah tidak adanya ketentuan dari penyedia jasa tentang mekanisme pengantaran berdasarkan jenis barang yang diantar. Artinya, barang yang harganya mahal atau sifatnya berharga akan diperlakukan sama dengan barang biasa.

Dalam konteks UU No. 8 Tahun 1999 tentang Perlindungan Konsumen kedudukan hukum perusaan transportasi online (PT Go-Jek Indonesia) adalah sebagai Pelaku usaha, sedangkan pengguna jasa adalah sebagai konsumen di mana keduanya memiliki hak dan kewajiban masing-masing.

\footnotetext{
"Terjadi Lagi, Kurir Go-Send Bawa Kabur Barag Pesanan Pelanggan", https://www.kaskus.co.id/thread/5b974734902cfe82218b4567/terjadi-lagi-kurir-go-send-bawa-kabur-barangpesanan-pelanggan/, diakses tanggal 29 Juli 2019.

${ }^{5}$ Candra Ahmadi dan Dadang Hermawan, E-Bussiness \& E-Commerce, Penerbit Andi bekerjasama dengan Stikom Bali, Yogyakarta, 2013, hlm. 40.

${ }^{6}$ Agus Yudha Hernoko, Hukum Perjanjian Asas Proporsionalitas dalam Kontrak. Komersial, Kencana, Jakarta, 2010, hlm. 15.
} 


\section{Rumusan Masalah}

Oleh karena kedudukan antara pelaku usaha dan konsumen yang tidak seimbang ini membuat penulis tertarik untuk mengkaji: Petama, bagaimana tanggung jawab Tokopedia dan Go-Jek atas keamanan barang kiriman konsumen dalam pengangkutan barang melalui jasa Go-Send instan courier? Kedua, apa langkah hukum yang dapat dilakukan konsumen apabila hak atas keamanan barang tidak didapatkan?

\section{Tujuan Penelitian}

Adapun tujuan dari penelitian ini sebagai berikut: Pertama, mengkaji tanggung jawab Tokopedia dan Go-Jek atas keamanan barang kiriman konsumen dalam pengangkutan barang melalui jasa Go-Send Instant Courier; dan Kedua, menganalisa langkah hukum yang dapat dilakukan konsumen apabila hak atas keamanan barang tidak didapatkan.

\section{Metode Penelitian}

Dalam penelitian ini digunakan pendakatan yuridis-empiris di mana akan diuraikan peraturan perundang-undangan yang berlaku yaitu Undang-Undang No. 8 Tahun 1999 tentang Perlindungan Konsumen dan realita penerapannya di lapangan. Hal tersebut untuk mengetahui das sein dan das solen terkait tema penelitian ini, khususnya pada tercapainya perlindungan konsumen yang sesuai dengan amanat peraturan perundang-undangan.

Objek penelitian dalam tesis ini adalah Perusahaan Tokopedia, Go-Jek Indonesia (PT. Aplikasi Karya Anak Bangsa), Mitra Go-Jek Indonesia (driver) dan konsumen pengguna layanan Go-Send Go-Jek Indonesia, juga kententuan di dalam Undang-Undang No. 8 Tahun 1999 tentang Perlindungan Konsumen dan juga Undang-Undang No 19 Tahun 2016 tentang Perubahan Atas UndangUndang No. 11 Tahun 2008 tentang Informasi dan Transaksi Elektronik dan Undang Undang No 38 Tahun 2009 tentang Pos.

Data penelitian pada dasarnya dibagi menjadi dua: primer dan sekunder. Data primer adalah data yang diperoleh langsung dari sumber data pertama, seperti wawancara dan/atau observasi langsung, sedangkan data sekunder adalah data yang didapatkan dari peraturan perundang-undangan, data olahan baik berupa buku, hasil penelitian atau berkas laporan. ${ }^{7}$

Adapun pengolahan dan penyajian data dalam penelitian ini adalah dengan mendiskripsikan data, yaitu menarasikan data yang telah diteliti dengan kata-

\footnotetext{
${ }^{7}$ Soerjono Soekanto, Pengukuran Penelitian Hukum, UI Press, Jakarta, 2010, hlm. 11-12.
} 
kata, baik berupa data primer seperti hasil wawancara maupun data sekunder yang terdiri dari bahan hukum primer, sekunder dan tersier.

Sedangkan metode analisis data dalam penelitian ini adalah analisis data deskriptif-kualitatif, yaitu penelitian yang menghasilkan data berupa kata tertulis yang dapat dipahami. Penulis akan melakukan pengelohan data yang kemudian dianalisis secara kualitatif menggunakan pendekatan silogisme deduktif induktif, yaitu mengambil kesimpulan khusus dari data-data umum dan sebaliknya. ${ }^{8}$

\section{Hasil Penelitian dan Pembahasan}

\section{Konsep Pengiriman/Pengangkutan Barang}

Kata 'pengiriman' tidak biasa dipakai dalam istilah hukum. Dalam istilah hukum, kata pengiriman biasa disebut pengangkutan. Di dalam hukum pengangkutan Indonesia, barang kiriman bisa juga disebut sebagai barang angkutan. Pengangkutan merupakan rangkaian kegiatan pemindahan penumpang atau barang dari suatu tempat pemuatan (embarkasi) ke tempat tujuan (debarkasi) sebagai tempat penurunan penumpang atau penurunan barang muatan. ${ }^{9}$

Oleh karena itu, dapat ditarik kesimpulan bahwa pengertian pengiriman barang adalah proses pemindahan barang dari satu tempat ke tempat lainnya.

Dalam Pasal 1 angka (3) Undang-Undang No. 22 Tahun 2009 tentang Lalu Lintas dan Angkutan Jalan, pengertian angkutan adalah perpindahan orang dan/atau barang dari suatu tempat ke tempat lain dengan menggunakan kendaraan di ruang lalu lintas jalan. Setidaknya terdapat 4 komponen yang terlibat dalam proses tersebut: Pengirim, Pengangkut (perusahaan dan/atau driver), Penerima dan Alat Angkut (kendaraan).

\section{Perkembangan Jasa Pengiriman Online}

Menurut Pasal 47 ayat (1) UU No. 22 Tahun 2009 tentang Lalu Lintas dan Angkutan Jalan kendaraan terdiri atas kendaraan bermotor dan kendaraan tidak bermotor. Kendaraan tidak bermotor adalah setiap kendaraan yang digerakkan oleh tenaga manusia dan/atau hewan, sedangkan kendaraan bermotor adalah setiap kendaraan yang digerakkan oleh peralatan mekanik berupa mesin selain kendaraan yang berjalan di atas rel. ${ }^{10}$

${ }^{8}$ Mundiri, Logika, Rajawali Press, Jakarta, 2012), hlm. 13.

${ }_{9}$ Abdulkadir Muhammad, Hukum Pengangkutan Niaga, Citra Aditya Bakti, Bandung, 2008, hlm. 48.

${ }_{10}$ Undang-Undang No. 22 Tahun 2009 tentang Lalu Lintas dan Angkutan Jalan, Pasal 1 ayat (8) dan ayat $(9)$. 
Dalam undang-undang tentang Lalu Lintas dan Angkutan Jalan terdapat beberapa pasal yang berhubungan langsung dengan pengangkutan barang, diantaranya adalah Pasal 137 ayat (3) dan Pasal 138 ayat (3) yang pada intinya mengatur tentang pengangkutan barang dengan kendaraan bermotor wajib menggunakan mobil barang, sedangkan angkutan orang dan/atau orang wajib menggukana kendaraan bermotor umum.

Berdasarkan Peraturan Pemerintah No 74 Tahun 2014 tentang Angkutan Jalan dalam Pasal 10 ayat (2) dapat kita pahami bahwa angkutan barang dapat dilakukan dengan mobil penumpang, mobil bus dan sepeda motor. Dan khusus angkutan barang menggunakan sepeda motor terdapat syarat-syarat khusus seperti disebutkan di atas. Dalam Pasal 11 PP No. 47 Tahun 2014 tentang Angkutan Jalan ini, semua kendaraan bermotor yang digunakan untuk angkutan barang ditekankan untuk memperhatikan faktor keselamatan.

Dalam menggunakan fitur Go-Send, pengirim barang dapat mengirimkan barangnya dengan mengakses aplikasi dan membayar sejumlah uang sebagai tarif dari jasa tersebut. Pengirim juga bisa memantau barang kirimannya secara langsung melalui aplikasi Go-Jek yang telah terkoneksi dengan sinyal GPS, sehingga pengirim dapat mengetahui di mana barang tersebut berada. Hal ini tentu sangat membantu kebutuhan konsumen. Meskipun demikian, jika dikaji secara hukum, layanan pengiriman (pengangkutan) barang melalui sepeda motor ini belum memikili payung hukum yang memadai. Bahkan, layanan ojek online ini pernah dilarang beroperasi oleh Menteri Perhubungan Republik Indonesia melalui Surat Nomor UM.302/1/21/Phb/2015, yang ditandatangani pada 9 November 2019. Surat ini ditujukan kepada Kepolisian Republik Indonesia, dengan tembusan Menteri Koordinator Bidang Politik Hukum dan Keamanan RI, Menteri Koordinator Bidang Perekonomian, Gubenur, Korlantas, Dirjen Perhubungan Darat, dan Ketua Umum DPP Organda.

Dalam Pasal 138 ayat (3) Undang-Undang Lalu Lintas dan Angkutan Jalan (UU LLAJ) disebutkan: angkutan umum orang dan/atau barang dilakukan hanya dengan menggunakan kendaraan bermotor umum. Dalam UU LLAJ memang tidak ada larangan angkutan orang/barang menggunakan sepeda motor. Namun, jika ditelaah lagi, terdapat aturan yang membatasi penggunaan angkutan umum. Dalam Pasal 138 ayat (3) tersebut ditentukan bahwa "hanya" kendaraan bermotor umum-lah yang dapat digunakan untuk mengangkut orang dan/atau barang.

Sejauh ini, belum ditemukan aturan mengenai angkutan umum menggunakan sepeda motor secara online. Selama ini, perusahaan Ojek Online masih bernaung di bawah Undang-Undang No. 11 Tahun 2008 tentang Informasi dan Transaksi Elektronik. 


\section{Hubungan Hukum Antara Tokopedia dan Go-Jek dalam Pengiriman Barang}

Hubungan hukum dapat timbul melalui dua jalan: pertama, lahir dari Peraturan Perundang-undangan. Kedua, lahir dari adanya perjanjian antara satu pihak dengan pihak lainnya. Hubungan hukum antara Tokopedia dan Go-Jek dalam pengiriman barang merupakan hubungan hukum yang timbul akibat dari adanya perjanjian antara keduanya. Perjanjian antara Tokopedia dan Go-Jek merupakan perjanjian antara pelaku usaha.

Posisi Tokopedia sebagai start-up Pasar Barang (marketplace),yaitu melayani jual beli barang, sedangkan Go-Jek adalah start-up Transportasi Online, diantaranya melayani pengiriman barang online jarak dekat, disebut layanan GoSend. Tokopedia dan Go-Jek memiliki satu jalur kepentingan yang sama, yaitu mendapatkan pelanggan sebanyak mungkin dan memberikan pelayanan dengan baik, cepat dan efisien.

Hubungan hukum antara Tokopedia dan Go-Jek merupakan hubungan hukum yang lahir akibat dari adanya perjanjian. Tokopedia sebagai sebuah sistem marketplace, bertugas memberikan ruang dibukanya layanan pengiriman menggunakan sistem layanan Go-Send milik Go-Jek.

\section{Pertanggungjawaban Hukum Tokopedia dan Go-Jek atas Keamanan Barang Kiriman Konsumen Pengguna Layanan Go-Send Instant Courier}

Siapa berbuat, dia yang bertanggungjawab. Begitulah kira-kira adigum yang hampir semua orang setujui. Di dalam hukum, dikenal asas pertanggungjawaban. Seseorang dianggap selalu bertanggungjawab atas segala perbuatan, akibat-akibat dari perbuatannya, tidak berbuat, kelalaian atau kurang hati-hatinya pada orang atau pihak lain. Tanggungjawab tersebut tergantung pada: apakah pada peristiwa (yang menimbulkan kerugian orang lain itu) terdapat kesalahan orang tersebut sehingga ia harus membayar ganti rugi (tanggung jawab berdasarkan kesalahan). Dalam kaitan ini, dikenal pula asas presumption of innocense (setiap orang dianggap tidak bersalah, sampai dibuktikan kesalahannya itu di hadapan pengadilan yang berwenang atasnya). ${ }^{11}$

Dalam kasus yang terjadi pada Yassier (baca kembali Bab I), Nomor Resi Pengiriman Go-Send adalah GK-104151122. Nomer ini selanjutnya berfungsi sebagai bukti telah terjadinya perjanjian pengiriman barang melalui jasa pengiriman Go-Send antara Yassier dengan Go-Jek melalui aplikasi pihak ketiga. Meskipun demikian, Yasier di sini tidak mengakses aplikasi Go-Jek untuk memesan jasa Go-Send. Yassier melakukan pemesanan Go-Send (secara tidak

11 A.Z Nasution, Konsumen dan Hukum, Pustaka Sinar Harapan, Jakarta, 1995, hlm. 171. 
langsung) melalui aplikasi pihak ketiga yaitu Tokopedia, tempat dia membeli Handphone Xiaomi Redmi S2 RAM 3GB Internal 32GB.

Dari Aplikasi Tokopedia Yassier mendapatkan nomer resi otomatis yang terhubung dengan Go-Jek. Sehingga dalam kasus ini, unsur perjanjian pengangkutan telah terpenuhi dengan adanya bukti resi tersebut. Jadi, apabila terjadi suatu kehilangan barang yang dikirimkan melalui Go-Send, Yassier berhak untuk meminta pertanggung jawaban kepada pihak Tokopedia sebagai perantara, dan Go-Jek sebagai penyedia jasa pengiriman.

Dalam kasus hukum pengangkutan dan perlindungan konsumen, terdapat 5 prinsip tanggung jawab:

\section{Tanggung jawab karena kesalahan (fault liability)}

Prinsip tanggungjawab berdasarkan kesalahan merupakan prinsip umum dalam hukum pidana dan hukum perdata. Prinsip ini menyatakan, seseorang baru dapat dimintakan pertanggungjawabannya secara hukum jika ada unsur kesalahan yang dilakukannya. ${ }^{12}$

Prinsip ini dianut dalam Pasal 1365, 1366 dan 1367 Kitab Undang Undang Hukum Perdata (KUHPer) tentang perbuatan melawan hukum (illegal act) sebagai aturan umum (general rule). Sedangkan aturan khususnya ditentukan berdasarkan undang-undang yang mengatur masing-masing jenis angkutan. ${ }^{13}$

Beban pembuktian ada pada pihak yang dirugikan, di mana pihak yang menderita kerugian wajib membuktikan kesalahan pengangkut. Berdasarkan prinsip ini, konsumen diberi tanggung jawab untuk membuktikan adanya unsur kesalahan pelaku usaha yang merugikan konsumen. ${ }^{14}$

Prinsip ini mengikuti ketentuan Pasal 163 Herziene Indonesische Reglement (HIR) atau Pasal 283 Rechtsreglement Buitengewesten (Rbg) dan Pasal 1865 KUHPer yang pada intinya bermakna: barang siapa mengakui suatu hak, maka harus membuktikan adanya hak atau peristiwa itu (actorie incumbit probatio). Teori ini juga sejalan dengan asas umum dalam hukum acara yaitu audi et altern partem (memiliki kedudukan yang sama antara semua pihak berperkara). ${ }^{15}$

Hal lain yang perlu diperhatikan dalam prinsip ini adalah subjek/pelaku kesalahan (lihat Pasal 1367 KUHPer). Dalam doktrin hukum dikenal asas vicarious liability dan corporate liability. Vicarious liability atau disebut juga respondeat superior, let the master answer adalah asas yang mengandung pengertian: majikan

12 Sidharta, Op. Cit., hlm. 73.

${ }^{13}$ Ibid.

${ }^{14}$ Erman Rajagukguk, et. al., Hukum Perlindungan Konsumen, Mandar Maju, Bandung, 2000, hlm. 24-26.

15 Andi Sri Rezky Wulandari dan Nurdiyana Tadjuddin, Hukum Perlindungan Konsumen, Mitra Wacana Media, Jakarta, 2018, hlm. 42. 
bertanggung jawab atas kerugian pihak lain yang ditimbulkan oleh orang-orang yang berada di bawah pengawasannya (captain of the ship doctrine).

Adapun corporate liability pada prinsipnya hampir sama dengan vicarious liability namun dalam doktrin ini pertangung jawaban hukum ditanggung oleh perusahaan/lembaga/korporasi bukan "majikan".16 Dalam kasus Yassier ini, Yassier dapat meminta pertanggung-jawaban kepada Tokopedia atau Go-Jek, baik secara sendiri-sendiri maupun bersama-sama. Pihak Go-Jek dianggap sebagai perusahaan yang bertanggung jawab atas kerugian Yassier yang ditimbulkan oleh driver yang berada di bawah pengawasannya.

\section{Tanggung Jawab Karena Praduga (presumption liability) atau Prinsip Praduga untuk Selalu Bertanggung Jawab}

Prinsip ini menyatakan, tergugat selalu dianggap bertanggungjawab (presumption of liability principle), sampai ia dapat membuktikan, ia tidak bersalah. ${ }^{17}$ Prinsip ini menerima asas pembuktian terbalik (omkering van bewijslast), yaitu seseorang dianggap bersalah sampai yang bersangkutan dapat membuktikan sebaliknya. Dalam Undang-Undang Perlindungan Konsumen, pembuktian terbalik dapat ditemukan dalam Pasal 19, 22, 23 dan 28. ${ }^{18}$ Dalam hukum pengangkutan asas ini hanya dijumpai dalam Undang-Undang Pelayaran Indonesia. ${ }^{19}$ Kasus Yassier tidak dapat dimasukkan dalam prinsip ini. Sebab sangat jelas, bahwa perbuatan pengangkut (driver) adalah membawa kabur barang kirimannya dengan cara melawan hukum.

\section{Prinsip Praduga untuk Tidak Selalu Bertanggung Jawab (presumption of nonliability principle)}

Prinsip ini adalah kebalikan dari prinsip kedua. Prinsip praduga untuk tidak selalu bertanggungjawab hanya dikenal dalam lingkup transaksi konsumen yang sangat terbatas. Contoh dari penerapan prinsip ini adalah pada hukum pengangkutan. Kehilangan atau kerusakan pada bagasi kabin/bagasi tangan, yang biasanya dibawa dan diawasi oleh si penumpang (konsumen) adalah tanggung jawab dari penumpang. Dalam hal ini pengangkut tidak dapat dimintai pertanggungjawaban atas kehilangan atau kerusakan barang tersebut. ${ }^{20}$

Meskipun demikian, dalam Pasal 44 ayat (2) Peraturan Pemerintah Nomor 40 Tahun 1995 tentang Angkutan Udara, disebutkan bahwa prinsip ini tidak lagi

\footnotetext{
${ }^{16}$ Ibid.

${ }^{17}$ Sidharta, Op. Cit., hlm. 75.

${ }^{18}$ Ibid.

${ }^{19}$ Abdulkadir Muhammad, Op. Cit., hlm. 54.

20 Shidarta, Op. Cit., hlm. 77.
} 
diterapkan secara mutlak, dan mengarah pada prinsip tanggungjawab dengan pembatasan uang ganti rugi (setinggi-tingginya satu juta rupiah). Artinya, bagasi kabin/bagasi tangan tetap dapat dimintakan pertangungjawaban sepanjang bukti kesalahan pihak pengangkut (pelaku usaha) dapat ditunjukkan. Beban pembuktian berada pada konsumen. ${ }^{21}$

\section{Prinsip Tanggung Jawab dengan Pembatasan (limitation of liability principle)}

Prinsip ini sangat disenangi oleh pelaku usaha untuk dicantumkan sebagai klausula eksonerasi dalam perjanjian standar yang dibuatnya. Prinsip ini biasanya dikombinasikan dengan prinsip tanggung jawab lainnya. Dalam pengangkutan udara, yakni Pasal 17 ayat (1) Protokol Guatemala 1971, prinsip tanggung jawab dengan pembatasan dikaitkan dengan prinsip tanggung jawab mutlak. Batas tanggung jawab pengangkut untuk satu penumpang sebesar 100.000 dolar Amerika Serikat (tidak termasuk biaya perkara) atau 120.000 dolar (termasuk biaya perkara). ${ }^{22}$ Prinsip tanggung jawab ini sangat merugikan konsumen bila ditetapkan secara sepihak oleh pelaku usaha.

\section{Tanggung jawab mutlak (absolute liability)}

Prinsip tanggung jawab mutlak dalam hukum perlindungan konsumen disebut product liability. Asas tanggung jawab mutlak biasanya digunakan untuk "menjerat" pelaku usaha, khususnya produsen barang yang merugikan konsumen. Meskipun demikian, menurut Abdulkadir Muhammad, prinsip ini tidak diatur di dalam undang-undang, namun dapat dipakai di dalam perjanjian apabila para pihak menghendakinya. ${ }^{23}$ Hukum pengangkutan Indonesia umumnya menganut prinsip tanggung jawab karena kesalahan (fault liability) dan karena praduga (presumption liability). ${ }^{24}$

Dari penjelasan di atas kita dapat mengambil kesimpulan bahwa dalam kasus Yassier ini, berlaku prinsip tanggung jawab karena unsur kesalahan. Prinsip ini membebankan Yassier untuk memberikan pembuktian bahwa dirinya telah kehilangan barang yang dia beli di Tokopedia, dan dibawa kabur oleh driver Go-Send. Yasier dapat meminta pertanggung jawaban kepada Tokopedia, Go-Jek maupun driver Go-Send itu sendiri, selama Yasier dapat membuktikan bahwa dirinya telah dirugikan oleh ketiganya.

Ketentuan mengenai pembuktian selain dapat ditemukan dalam hukum acara yang berlaku (HIR dan RBg), juga dapat ditemukan dalam Buku IV Kitab

\footnotetext{
${ }^{21}$ Ibid.

22 Ibid., hlm. 79-80.

${ }^{23}$ Ibid., hlm. 56.

${ }^{24}$ Ibid., hlm. 49.
} 
Undang-Undang Hukum Perdata. Berdasarkan Pasal 163 HIR dan Pasal 1865 Kitab Undang-Undang Hukum Perdata, dapat dikatakan bahwa setiap pihak yang mendalilkan adanya suatu hak, (yang dalam hal ini Yassier sebagai pembeli yang dirugikan), maka Yassier harus membuktikan bahwa:25

a. Yassier secara aktual telah mengalami kerugian;

b. Yassier juga harus membuktikan bahwa kerugian tersebut terjadi sebagai akibat dari penggunaan, pemanfaatan atau pemakaian jasa Go-Send yang tidak layak;

c. Bahwa ketidak-layakan dari penggunaan, pemanfaatan atau pemakaian dari jasa tersebut merupakan tanggung jawab dari Go-Jek dan Tokopedia;

d. Yassier tidak "berkontribusi", baik secara langsung atau pun tidak langsung atas kerugian yang dideritanya tersebut.

\section{Penyelesaian Sengketa dan Penegakan Hukum atas Hilangnya Barang Kiriman Konsumen Melalui Go-Send}

Penyelesaian sengketa konsumen, menurut Pasal 45 ayat (2) UndangUndang Nomor 8 Tahun 1999 tentang Perlindungan Konsumen, dapat ditempuh melalui dua cara:

\section{Penyelesaian sengketa di luar pengadilan}

a. Penyelesaian secara damai oleh para pihak sendiri;

Penyelesaian sengketa konsumen sebagaimana dimaksud dalam Pasal 45 ayat (2) UUPK, tidak menutup kemungkinan dilakukannya penyelesaian sengketa secara damai oleh para pihak yang bersengketa, tanpa melalui Badan Penyelesaian Sengketa Konsumen (BPSK) dan sepanjang tidak bertentangan dengan UUPK.

b. Penyelesaian sengketa melalui lembaga yang berwenang, yaitu melalui BPSK dengan menggunakan mekanisme mediasi, konsiliasi dan arbitrase.

Jika usaha damai antara para pihak tidak dapat ditempuh, maka menurut Pasal 45 ayat (2) UUPK, penyelesaian sengketa di luar pengadilan dapat ditempuh melalui mediasi, konsiliasi dan arbitrase di Badan Penyelesaian Sengketa Konsumen (BPSK). Dengan adanya BPSK, maka penyelesaian sengketa konsumen dapat dilakukan dengan cepat, mudah dan murah. Cepat karena UUPK menentukan tenggang waktu 21 hari kerja, BPSK wajib memberikan putusannya. ${ }^{26}$

${ }^{25}$ Gunawan Widjaja dan Ahmad Yani, Hukum tentang Perlindungan Konsumen, Gramedia Pustaka Utama, Jakarta, 2001, hlm. 68-69.

26 Yusuf Shofie dan Somi Awan, Sosok Peradilan Konsumen Mengungkap Berbagai Persoalan Mendasar BPSK, Piramedia, Jakarta, 2004, hlm. 17. 
c. Penyelesaian sengketa di pengadilan

Ketika upaya perdamaian gagal dicapai, atau para pihak tidak mau lagi menempuh jalur perdamaian, maka para pihak dapat menyelesaikan sengketanya melalui jalur pengadilan dengan cara:

i. Gugatan perdata konvensional

ii. Gugatan perwakilan/gugatan kelompok (class action)

iii.Gugatan/hak gugat LSM (Legal Standing)

iv.Penyelesaian secara pidana

Konsumen dapat mengajukan gugatan ke Pengadilan Negeri tempat kedudukan konsumen. Dengan berlakunya UUPK, ketentuan dalam Pasal 118 HIR tentang Asas actor sequitur forum rei dikesampingkan. UUPK dalam Pasal 23 jo Pasal 45 sebagai lex spesialist, menentukan bahwa Penggugat (Konsumen) mengajukan gugatannya di Pengadilan tempat konsumen tinggal. Hal ini dibenarkan berdasarkan asas lex spesialist, derogat legi generalis. Ketentuan Pasal 23 jo Pasal 45 UUPK merupakan ketentutan acara perdata khusus yang harus diterapkan dalam rangka pengajuan gugatan oleh konsumen kepada pelaku usaha.

Dalam kasus Yasier ini, penyelesaian sengketa dilakukan dengan cara damai antara pihak Yasier, Tokopedia dan Go-Jek. Hal tersebut dilakukan Yasier dengan menggunakan fasilitas komplain yang disediakan oleh Tokopedia. Berdasarkan hasil komplain, Yasier menerima bentuk ganti kerugian dengan pengembalian uang ke dalam saldo Tokopedia, yang diberikan setelah dia melakukan pengajuan klaim asuransi kepada pihak Tokopedia. Yasier dijanjikan mendapatkan uangnya kembali tetapi tidak sesuai dengan yang dibayarkan saat pembelian Handphone Xiaomi Redmi S2 Ram 3GB Internal 32 GB Garansi TAM dan ongkir yang dibayarkan, yaitu sebesar Rp. 1.829.490,00, Yasier hanya mendapatkan ganti kerugian sebesar Rp. 1.806.000,00. Setelah menunggu selama 14 hari, Yasier ternyata tidak mendapatkan uang yang dijanjikan secara utuh. Yasier hanya mendapatkan ganti kerugian sebesar Rp. 1.786.000,00.

Dasar kerugian ini, membuka peluang Yasier untuk melakukan Pengajuan Gugatan Ganti Kerugian melalui Pengadilan Negeri atau dapat pula mengirimkan surat pengaduan kepada BPSK atas kerugian yang telah dideritanya. Yasier dapat mengajukan gugatan kepada Pihak Tokopedia maupun Go-Jek dalam konteks perlindungan konsumen. Sedangkan dalam perkara perdata dan pidana Yasier dapat pula melibatkan driver Go-Jek yang bersangkutan dalam gugatan perbuatan melawan hukum dan ganti kerugian. 


\section{Penutup}

Berdasarkan pembahasan di atas, dapat ditarik kesimpulan sebagai berikut: Pertama, secara de jure, tanggung jawab Tokopedia dan Go-Jek atas keamanan barang kiriman konsumen dalam pengangkutan barang melalui jasa Go-Send Instant Courier adalah tanggung jawab karena kesalahan dengan memperhatikan asas corporate liability, yaitu suatu korporasi/perusahaan dianggap bertanggung jawab atas kesalahan yang dilakukan oleh bawahan/orang yang berada di dalam pengawasannya yang menimbulkan kerugian pada orang lain. Secara de facto, pembelian di Tokopedia selalu dilindungi dengan asuransi, sehingga setiap terjadi kehilangan barang, Tokopedia akan mengganti/mengembalikan uangnya kepada Pembeli maupun kepada Penjual (Pengirim), begitu juga dengan penggunaan jasa kirim Go-Send Instant Courier. Dalam kasus Yasier, Tokopedia melakukan pengembalian sebagian besar dana handphone yang dibayarkan atau pengembalian dana tidak utuh dari seharusnya. Kedua, konsumen dapat melakukan langkah hukum apabila hak atas keamanan barang tidak didapatkan, diantaranya sebagai berikut: a. mengajukan komplain kepada Tokopedia atau GoJek untuk menyelesaikan kasus yang terjadi, apabila tidak ada respon positif, maka konsumen dapat; b. mengajukan gugatan kepada Badan Penyelesaian Sengketa Konsumen; c. mengajukan gugatan perdata ke Pengadilan Negeri tentang Perbuatan Melawan Hukum.

Selama ini, belum ditemukan konsumen yang menempuh jalur hukum dengan mengajukan gugatan ke Badan Penyelesaian Sengketa Konsumen, atau ke Pengadilan Negeri. Masalah kehilangan barang biasanya diselesaikan langsung oleh Tokopedia dengan melakukan refund dana kepada konsumen. Biasanya, setelah komplain masuk sistem Tokopedia, konsumen diminta untuk menunggu hasil investigasi selama 14 hari untuk dilakukan investigasi oleh Tim Tokopedia dan Go-Jek untuk melacak keberadaan barang dan jika terbukti barang tersebut hilang, maka refund akan otomatis ditransfer ke akun/saldo Tokopedia yang bersangkutan dalam tenggat waktu 48 jam.

\section{Daftar Pustaka}

\section{Buku}

Ahmadi, Candra dan Dadang Hermawan, E-Bussiness \& E-Commerce, Penerbit Andi bekerjasama dengan Stikom Bali, Yogyakarta, 2013.

Asnawi, Faulidi Haris, Transaksi Bisnis E-Commerce Perspektif Islam, Magistra Insania Press, Yogyakarta, 2004. 
Badrulzaman, Mariam Darus, KUHPerdata Buku III Hukum Perikatan dengan Penjelasan. Alumni, Bandung, 1983.

Emirzon, Joni, Alternatif Penyelesaian Sengketa di Luar Pengadilan, Gramedia Pustaka Utama, Jakarta, 2001.

Fuady, Munir, Hukum Kontrak, Citra Aditya Bakti, Bandung, 2015.

Hernoka, Agus Yudha, Hukum Perjanjian Asas Proporsionalitas dalam Kontrak Komersia, Kencana, Jakarta, 2010.

Kotler, Philip P., Prinsip-Prinsip Pemasaran, Erlangga, Jakarta, 2014.

Kurniawan, Hukum Perlindungan Konsumen, Problematika Kedudukan dan Kekuatan Putusan Badan Penyelesaian Sengketa Konsumen (BPSK), UB Press, Malang, 2011.

Maskun, Kejahatan Cyber (Cyber Crime), Kencana Prenada Group, Bandung, 2013.

Mertokusumo, Sudikno, Mengenal Hukum Suatu Pengantar, Liberty, Yogyakarta, 1986.

Miru, Ahmadi dan Sutarman Yodo, Hukum Perlindungan Konsumen, Cetakan Kedelapan, Rajawali Press, Jakarta, 2014.

Muhammad, Abdulkadi, Hukum Pengangkutan Niaga, Citra Aditya Bakti, Bandung, 2008.

Nasution, A.Z., Konsumen dan Hukum, Sinar Harapan, Jakarta, 1995.

Projodikoro, Wirjono, Azas-Azas Hukum Perjanjian, Mandar Maju, Bandung, 2011.

Rajagukguk, Erman et.al., Hukum Perlindungan Konsumen, Cetakan Pertama, Mandar Maju, Bandung, 2000.

Ramli, Ahmad M., Cyber Law dan HAKI dalam Sistem Hukum Indonesia, Refika Aditama, Jakarta, 2004.

Rosmawati, Pokok-Pokok Hukum Perlindungan Konsumen, Kencana, Jakarta, 2018.

Shofie, Yusuf dan Somi Awan, Sosok Peradilan Konsumen Mengungkap Berbagai Persoalan Mendasar BPSK, Piramedia, Jakarta 2004.

Sidharta, Hukum Perlindungan Konsumen Indonesia, Grasindo, Jakarta, 2006.

Soekanto, Soerjono, Faktor-Faktor yang Mempengaruhi Penegakan Hukum, Rajawali Press, Jakarta, 2007.

Subekti, Hukum Perjanjian, Intermasa, Jakarta, 2002.

Tanya, Bernard L., Teori Hukum Strategi Tertib Manusia Lintas Ruang dan Generasi, Genta Publishing, Yogyakarta, 2013.

Usman, Rachmadi, Pilihan Penyelesaian Sengketa di Luar Pengadilan, Citra Aditya Bakti, Bandung, 2003.

Wardiono, Kelik. Hukum Perlindungan Konsumen Aspek Substansi Hukum, Stuktur Hukum dan Kultur Hukum dalam UU No 8 Tahun 1999 tentang Perlindungan Konsumen, Penerbit Ombak, Yogyakarta, 2014.

Wijaya, Andika. Aspek Hukum Bisnis Transportasi Jalan Online, Sinar Grafika, Jakarta, 2016. 
Wulandari, Andi Sri Rezzky dan Nurdiyana Tadjuddin, Hukum Perlindungan Konsumen, Mitra Wacana Media Penerbit, Jakara, 2018.

\section{Jurnal}

Agung Ayu Krisnanti Larasati, Anak dan Made Maharta Yasa, "Pertanggungjawaban Go-Jek Akibat Kehilangan Barang Pada Fitur GoSend Sebagai Layanan yang Ditawarkan dalam Go-Jek Indonesia", Jurnal Kertha Patrika, Vol. 3, 2018.

Halim, Stefani Erlina, dan Siti Nurbaiti, "Perlindungan Hukum Terhadap Konsumen Transportasi Berbasis Online yang Menggunakan Driver Cadangan", Jurnal Hukum Adigama, Vol. 5, 2018).

\section{Tugas Akhir}

Giantama, Mahendra Arga, Perlindungan Hukum Terhadap Penumpang Atas Kecelakan Penumpang Jasa Transportasi Online: Studi Layanan Go-Ride yang Diselenggarakan oleh PT. Go-Jek Indonesia, Skripsi, Fakultas Hukum Universitas Islam Indonesia, Yogyakarta, 2018).

Islamikov, Joy, Hubungan Hukum Para Pihak dan Pertanggungjawaban Pada Jasa Go-Send PT. Go-Jek Indonesia, Skripsi, Fakultas Hukum Universitas Islam Indonesia, Yogyakarta, 2018.

\section{Internet}

"Syarat dan Kententuan Pengiriman dengan Go-send di Tokopedia", https://www.tokopedia.com/help/article/gosend, diakses tanggal 03 Feburari 2020.

"Terjadi Lagi, Kurir Go-Send Bawa Kabur Barag Pesanan Pelanggan", https://www.kaskus.co.id/thread/5b974734902cfe82218b4567/terjadilagi-kurir-go-send-bawa-kabur-barang-pesanan-pelanggan/, diakses tanggal 29 Juli 2019.

\section{Peraturan Perundang-Undangan}

Kitab Undang-Undang Hukum Perdata.

Kitab Undang-Undang Hukum Pidana.

Undang-Undang Nomor 8 Tahun 1999 tentang Perlindungan Konsumen.

Undang-Undang Nomor 19 Tahun 2016 tentang Perubahan Atas Undang-Undang Nomor 11 Tahun 2008 tentang Informasi dan Transaksi Elektronik.

Undang-Undang Nomor 22 Tahun 2009 tentang Lalu Lintas dan Angkutan Jalan . Undang-Undang Nomor 38 Tahun 2009 tentang Pos.

Kepmenperindag No.350/MPP/12/2001 tentang Pelaksanaan Tugas dan Wewenang Badan Penyelesaian Sengketa Konsumen. 